\title{
Yeni Dinî Hareketlerin Salgın Hastalıklar ve Tedavi Yöntemleri Karşısındaki Tutum ve Davranışları
}

\author{
Attitudes and Behaviors of New Religious Movements towards \\ Epidemics and Their Treatment Methods
}

\begin{abstract}
Emine Battal
Dr. Öğr. Üyesi, Recep Tayyip Erdoğan Üniversitesi İlahiyat Fakültesi emine.battal@erdogan.edu.tr \& https://orcid.org/000o-0001-6699-4237
\end{abstract}

\begin{tabular}{|c|c|}
\hline $\begin{array}{l}\text { Makale Türü } \\
\text { Article Type }\end{array}$ & $\begin{array}{l}\text { Araştırma Makalesi } \\
\text { Research Article }\end{array}$ \\
\hline $\begin{array}{l}\text { Geliş Tarihi } \\
\text { Date Received }\end{array}$ & 30.10 .2021 \\
\hline $\begin{array}{l}\text { Kabul Tarihi } \\
\text { Date Accepted }\end{array}$ & 07.12 .2021 \\
\hline $\begin{array}{l}\text { Yayın Tarihi } \\
\text { Date Published }\end{array}$ & 31.12.2021 \\
\hline $\begin{array}{l}\text { Atıf } \\
\text { Citation }\end{array}$ & $\begin{array}{l}\text { Emine Battal. "Yeni Dinî Hareketlerin Salgın Hastalıklar ve Tedavi } \\
\text { Yöntemleri Karşısındaki Tutum ve Davranışları". Oksident 3/2 (2021):157-179. }\end{array}$ \\
\hline $\begin{array}{l}\text { İntihal } \\
\text { Plagiarism }\end{array}$ & $\begin{array}{l}\text { Bu makale, Turnitin yazılımı ile taranmış ve intihal tespit edilmemiştir. } \\
\text { This article has been scanned by Turnitin and no plagiarism detected. }\end{array}$ \\
\hline Doi & https://doi.org/10.51490/oksident.1016622 \\
\hline
\end{tabular}


Öz

Koronavirüs yayılmaya başladıktan sonra salgin toplumsal, ekonomik, siyasal olduğu kadar dinî perspektiften de değerlendirmeye tabi tutulmuş ve farkh inanç sistemlerinin bu tür hastalıklara nasll baktığr gündeme gelmiştir. XX. yüzyılın ikinci yarısından sonra ortaya çlkmaya başlayan ve yeryüzünün inanç haritasının önemli bir parçası haline gelen Yeni Dinî Hareketler de konu ile ilgili tartışmalardaki yerini almıştır.

Bu makalede ilk olarak Yeni Dinî Hareketlerin salgin hastallklarn nasıl yorumladıklarn ele alınmıştır. Ardından Covid-19 salgın tedbirleri kapsaminda getirilen kisitlamalara yönelik tepkileri ya da yaşanan bu kriz karşısındaki çözüm önerileri tespit edilmeye çalışlımış, son olarak da birey ve toplum sağlığın korumak amacıyla geliştirilen aşıların uygulanması karşısındaki tutum ve dauranışlar incelenmiştir. Bir yandan Yeni Dinî Hareketlerin sayıca çokluğu diğer taraftan salgin hastalıklara yönelik tutum ve yaklaşımlarm çeşitliliği, söz konusu hareketlerin tamaminin konu ile ilgili düşünceleri ile pratikteki uygulamalarından bahsetmeyi oldukça zor, hatta imkânsız bir girişim haline getirmektedir. Bu nedenle örnek olarak daha ziyade salgin döneminde gerek söylemleri ile gerekse eylemleriyle öne geçerek kendisinden söz ettirmeyi başaran hareketlere müracaat edilmiştir.

Anahtar Kelimeler: Yeni Dinî Hareketler, Salgın Hastalık, Covid-19, Aşı.

\section{Abstract}

After the Coronavirus started to spread, the epidemic has been evaluated in terms of social, economic, political, and religious perspectives. How different belief systems view such diseases came to the fore. The New Religious Movements, which started to emerge after the second half of the 2oth century and became an essential part of the world's belief map, also took their place in the discussions on the subject. Firstly, this article has been discussed how New Religious Movements interpret the epidemics. Then their reactions to the restrictions within the scope of Covid-19 measures or their solution to the crisis has been tried to determine. Finally, attitudes and behaviors towards the application of vaccines developed to protect individual and public health have been examined. Many New Religious Movements or the diversity of perspectives and approaches towards the epidemics make it very difficult to talk about their thoughts and practical applications. For this reason, the movements that come to the fore with their discourses and actions during the epidemic period are discussed in the article.

Keywords: New Religious Movements, Epidemic, Covid-19, Vaccine. 


\section{Özet}

Dünya tarihi boyunca farklı dönemlerde çeşitli salgın hastalıklar ortaya çıkmıştır. Hızlı bir şekilde yayılan ve toplu ölümlere yol açan bu hastallklar, toplumların hayatını derinden etkilemiştir. Toplumların hafizasında ve psikolojisinde derin izler birakan salgin hastalıklar karşısında çeşitli mücadele yöntemleri ve yaklaşımlar geliştirilmiştir. Bu noktada başvurulan alanlardan birisi din olmuştur. Nitekim farklı inanç sistemlerinin salgın hastalıkları nasıl yorumladıkları ve toplum sağlığını korumak amacıyla ne tür çözüm önerilerinde bulundukları tespit edilmeye çalışılmıştır. 2019 yllında Çin'in Wuhan kentinde Covid-19'un ortaya çıkması ve kısa süre içerisinde tüm dünyayı etkisi altına almasiyla birlikte dinlerin salginlara yönelik değerlendirmeleri tekrar gündeme gelmişsir. Bu tartışmalarda geleneksel dinlerin bakış açılarının yanı sıra artık Yeni Dinî Hareketlerin yaklaşımlarına da yer verilmeye başlanmıştır.

Yeni Dinî Hareketler, insanlık için bir tehdit olarak telakki edilen salgin hastalıklara yönelik farklı yorumlar ortaya koymuştur. Bu çerçevede bazı hareketler söz konusu hastalıkları dünyanın son günlerinin belirtisi olarak değerlendirmiş̧ir. Yehova şahitleri salgınları böyle yorumlayan gruplardan biridir. Onlara göre Kutsal Kitap salgınlardan ismen söz etmemiş ama dünyanın son günlerinde bu tür hastalıkların yaşanacağını bildirmiştir. Mormon Kilisesi'nin de aralarında yer aldığı bazı hareketler ise salgın hastalıkların yaygınlaşmasını insanların inançsızlıklarıyla ilişkilendirmiştir. Ancak Mormon Kilisesi salgınların sebebini sadece inançsızlıkla sınırlı tutmamıştır. İnsanların işlemiş oldukları günahlar ile yaptıkları kötülükleri de salgınla cezalandırılmanın sebepleri arasında zikretmiştir.

Salginların yorumlanmasinda ortaya çıkan bu farklılık söz konusu hastalıklar karşısında alınan tedbirlerin desteklenmesi

\section{Summary}

Throughout the world's history, various epidemics have emerged in different periods. These epidemics, which spread rapidly and caused mass deaths, have profoundly affected the lives of societies. Various struggle methods and approaches have been developed against the epidemics. Religion has been one of the fields applied at this point. It has been tried to determine how different belief systems interpret epidemics and their solutions to protect public health. With the emergence of Covid-19 in Wuhan (China) in 2019 and its effect on the whole world in a short time, the evaluations of religions on epidemics have been brought to the agenda again. These discussions have also started to be included in the approaches of New Religious Movements and the perspectives of traditional religions.

New Religious Movements have put forward different interpretations on epidemics that are considered a threat to humanity. In this context, some movements commented on the epidemics mentioned above as the signs of the world's last days. Jehovah's Witnesses is one of the groups that interpret the epidemics in this way, arguing that the Bible did not mention the epidemics by name but stated that such diseases would occur in the world's last days. Some movements, including the Mormon Church, have associated the spread of epidemics with people's unbelief. The Mormon Church did not limit the cause of the epidemics to just unbelief. It also mentioned peoples' sins and vices among the reasons for being punished with an epidemic.

This difference in the 
noktasında da görülmektedir. Mesela Yehova Şahitleri, salgın hastalıklar karşısında kişilerin hem kendilerini hem de başkalarını koruyabilmeleri için gerekli olan tedbirlerin alınması gerektiğini savunmuştur. Nitekim Yehova Şahitleri bu düşünce doğrultusunda, Covid-19 salgını baş gösterdiğinde hükümetler henüz kısitlamalar koymadan önce ev ziyaretlerini durdurmuşlardır. Sokağa çıkma yasaklarının uygulanmaya başlamasıyla birlikte İbadet Salonları'nda yaptıkları halka açı toplantı düzenlemeyi bırakmışlardır. Scientology Hareketi de Covid-19 salgını sürecinde büyük toplantılarını iptal etmiş, ayrıca bültenler yayınlayarak taraftarlarına sağduyu çağrısında bulunmuştur. Yine Hare Krishna, koronavirüsün yayılmasını engellemek adına dünyanın farklı bölgelerinde faaliyet yürüten mabet ve toplanma merkezlerini kapatmıştır. Öte yandan tedbirlere uyma konusunda kayitsız davranan hareketlerin bulunduğu da bilinmektedir. Mesela Shincheonji, virüsün yayılması konusunda kendilerine yöneltilen eleştirilerle dikkat çekmiştir. Öyle ki Covid-19 salgının ilk aylarında, virüsün yayılmasına sebep oldukları gerekçesiyle, hükümetten söz konusu hareketin dağıtılması istenmiştir.

Yeni Dinî Hareketler, salgın hastalıkların giderilmesinde hangi yollara başvurdukları ya da aşı da dâhil olmak üzere önerilen korunma ve tedavi yöntemlerine nasıl tepki verdikleri ile de gündeme gelmektedir. Söz konusu hareketlerin bir kısmı tıbbi tedavilerin salginları önleyemediğini ileri sürmüş, dolayısıyla uygulanmalarına sıcak bakmamıştır. Diğer bazı hareketler ise tam aksine bilime güvenilmesi gerektiğinin altını çizmiş, bu doğrultuda da katılımcılarını tıbbi tedavileri kabul etmeye yönlendirmiştir. $\mathrm{Bu}$ çerçevede Yehova Şahitleri, Kutsal Kitap ilkeleri ile çeliştiği gerekçesiyle kan ve organ nakli gibi bazı tedavi şekillerini kabul etmemektedir. Bununla birlikte tıbbi tedavilere bütünüyle interpretation of epidemics also supports the measures against such diseases. For example, Jehovah's Witnesses advocate all necessary steps against the epidemics. They had stopped their home visits even before government-imposed restrictions when the Covid-19 pandemic arose. With imposing curfews, they stopped holding public meetings in Kingdom Halls. Scientology also canceled its large gatherings during the Covid-19 pandemic. It issued bulletins and called its supporters to common sense. Hare Krishna closed temples and collecting centers in different parts of the world to prevent the spread of the Coronavirus. It is also known that some movements do not comply with the measures. For example, Shincheonji has attracted attention with the criticisms directed at them regarding the spread of the virus. In the first months of the Covid-19 epidemic, the government was requested the dissolution of the movement on the grounds that they caused the spread of the virus.

New Religious Movements come to the fore with which methods they resorted to eliminating epidemics or reactions to the proposed prevention and treatment methods, including vaccines. Some of such movements claimed that medical treatments could not prevent epidemics, therefore, did not lean to their implementation. On the contrary, some other movements underlined that science should be trusted and directed their participants to accept medical treatments. For example, Jehouah's Witnesses do not take certain forms of treatment, such as blood and organ transplants, because they contradict Bible principles. 
karşı çıkma durumu da söz konusu değildir. Zira Kutsal Kitap ilkeleriyle çelişmediği düşünülen tedavi yöntemlerinden yararlandıkları ve ilaç kullandıkları bilinmektedir. Söz konusu tedavi yöntemlerinden hangisini tercih edecekleri ise kişilerin kendi kararlarına bırakılmaktadır. Yehova Şahitleri aşı konusunda da benzer bir tutum takınmakta, topyekün bir onay ya da karşıtlık sergilememektedir. Aşı olmak ya da çocuklarına aşı yaptırmak her bir hareket üyesinin kendisinin vermesi gereken bir karar olarak görülmektedir. Benzer şekilde Hare Krishna hareketinde de aşı konusunda herkesin bireysel olarak karar alabileceğine vurgu yapılmaktadır. Bununla birlikte doktorların açıklamalarına ve bilimsel çalışmaların verilerine güvenilmesinin yerinde olacağı da ifade edilmektedir.

Bazı hareketlerde liderler tarafından aşı karşıtlığı yapılmaktadır. 2006 yılında ABD'de ortaya çıkan Küresel Vizyon Kutsal Kitap Kilisesi'nin kurucusu ve lideri Gregory Duane Locke, Covid-19 aşısına karşı söylemleriyle kendinden söz ettirmiştir. Locke, Koronavirüs salgını hakkında pandeminin bir aldatmaca olduğunu, ölüm raporlarının manipüle edildiğini ileri sürmüştür. $\mathrm{Bu}$ iddialarına ayrıca aşların tehlikeli olduğunu ve virüsün kendisinden çok daha fazla ölüme yol açacağını da eklemiştir. Locke bu kadarla yetinmemiş ve bu süreçte cemaatinin toplantılarını iptal etmeyerek maske ve sosyal mesafe kurallarını ihlal etmiştir. Bunların haricinde bazı hareketler salgın ile mücadelede alternatif tekniklerini öne çıkarma yoluna gitmiştir. Mesela Falun Gong, kendi uygulamalarının Covid-19'un önlenmesi ve bu virüse bağlı ölüm riskini azaltması noktasında potansiyel bir faydaya sahip olduğunu ileri sürmüştür. Mesih Apostolik Kilisesi ve Kendini Gerçekleştirme Derneği gibi bazı hareketler ise salgın hastalıklarla en etkili mücadele yolu olarak duayı önermiştir.
However, it has not been wholly objected to medical treatments. It is known that they benefit from treatment methods that are not thought to contradict Bible Principle, and they use the medicine. Which treatment methods will be preferred is left to the individual's own decisions. Similarly, being vaccinated is also seen as a decision that each movement member has to make. In Hare Krishna, it is emphasized that everyone can make an individual decision about vaccination. It is stated that it would be appropriate to rely on the explanations of doctors and the data of scientific studies.

In some movements, leaders are opposed to vaccination. Gregory Duane Locke, the founder, and leader of the Global Vision Bible Church, which emerged in the USA in 2006, has made a name for himself with his rhetorics against the Covid19 vaccine. He claimed that the coronavirus epidemic was a hoax, that death reports had been manipulated. Locke also added to these claims that the vaccines are dangerous and will cause more deaths than the virus itself. In addition, he did not cancel the meetings of his congregation during this process and violated the rules for the mask and social distance. On the other hand, some movements have put forward alternative techniques to fight against the epidemic. For example, Falun Gong has claimed that its practices have a potential benefit in preventing Covid-19 and reducing the risk of death from this virus. Some movements, such as Christ Apostolic Church and Self-Realization Fellowship, have suggested praying as the most effective way to fight the 
Anlaşılacağı üzere gerek salgın hastalıklara bakış açıları gerek alınan tedbirler karşısındaki tepkileri gerekse tedavi yöntemleri ve aşı ile ilgili tutumları kapsamında Yeni Dinî Hareketlerin tamamı hakkında genel geçer tanımlamalar ya da değerlendirmeler yapmak mümkün değildir. Bu nedenle salgınla mücadelenin seyrini olumsuz yönde etkileyenleri merkeze alarak bütün hareketler günah keçisi ilan edilmemelidir. Öte yandan bazı grupların halk sağlığını tehdit eden uygulamalarına yönelik mücadele stratejileri geliştirilmesinin de önemli bir sorumluluk olduğu unutulmamalıdır. epidemics.

It is impossible to make general definitions or assessments about all the New Religious Movements in the relevant discussions. Thus, all movements should not be made scapegoats by focusing on those that adversely affect the course of the fight against the epidemic. However, On the other hand, it should not be forgotten that it is an important responsibility to develop strategies to combat the practices of some groups that threaten public health. 


\section{Giriş}

Tarih boyunca farklı coğrafyalarda yaşam süren toplumların çeşitli salgın hastalıklara maruz ve onlarla mücadele etmek zorunda kaldıkları bilinmektedir. İnsanları en fazla etkileyen ve çok sayıda ölüme neden olan bu salgınların başta gelenleri arasında veba, sıtma, kolera, tifo, çiçek, grip, EBOLA, SARS, AIDS zikredilebilir. Mesela 50o'lü yıllarda başlayıp 70o'lü yılların ortasına kadar devam eden Jüstinyen vebası salgınında dünya nüfusunun yarısı (25-50 milyon kişi), 1346-1353 yılları arasında Avrupa'da meydana gelen ve "kara ölüm" olarak nitelendirilen veba salgınında kıta nüfusunun yaklaşık \%40'1 (15-125 milyon kişi) hayatını kaybetmiştir. 19181920 yllları arasında görülen İspanyol gribi sonucu milyonlarca insan ölmüsstür. ${ }^{1}$ Bunların haricinde 2003 yılında SARS, 2014'te EBOLA salgını da yine binlerce kişinin ölümüne yol açmıştır. ${ }^{2}$

Söz konusu salgınların en yakın tarihli örneğini ise Aralık 2019'da Çin'in Wuhan kentinde ortaya çıkan, Şubat 2020'den itibaren dünyanın pek çok bölgesinde yayılan ve halen tüm dünyayı etkisi altında tutmakta olan Yeni Tip Koronavirüs (Covid-19) oluşturmaktadır. İçinde bulunduğumuz yüzyılın en büyük halk sağlığı problemi olan ve milyonlarca kişinin ölümüne yol açan koronavirüs salgını, iktisadi ve siyasi alanın yanı sıra dinî açıdan da pek çok etki yaratmıştır. Yaşanan bu kriz karşısında farklı dinî yapılanmalar, kendi öğretileri doğrultusunda bir tutum ve bakış açısı geliştirmiştir. Mesela salgının yaygınlaştığı ilk dönemde bazı dinî liderler ve takipçileri hükümetlerin almış olduğu kararlara uygun davranma eğilimi göstererek ritüellerinde değişiklik yapma, hatta toplu olarak gerçekleştirilen birçok ibadeti askıya alma yoluna giderken bazıları ise tam tersi davranarak söz konusu pandemi kurallarına uymak istememiştir. ${ }^{3}$

Koronavirüs salgınının ilk haftalarında büyük dinî toplantıların virüsün yayılmasını tetiklediği bir realitedir. Ancak burada dikkat çeken husus pandeminin başlarında henüz kanunen kısıtlanmamış bu toplantıların aynı dönemlerde gerçekleşen ve yine kalabalık ortamların

TÜBA, "Covid 19 Pandemi Değerlendirme Raporu”, (TÜBA, 2020), 21.

Alex Knapp, "The Secret History of The First Coronavirus", erişim: 19.10.2021, https://www.forbes.com/sites/alexknapp/2020/04/11/the-secret-history-of-the-firstcoronavirus-229e; TÜBA, “Covid 19 Pandemi Değerlendirme Raporu”, 24-26.

$3 \quad$ Sayed A. Quadri, "COVID-19 and Religious Congregations: Implications for Spread of Novel Pathogens", International Journal of Infectious Diseases 96 (2020): 219-221; Vivian Yee, "In a Pandemic, Religion Can Be a Balm and a Risk", erişim: 10.10.2021, https://www.nytimes.com/2020/03/22/world/middleeast/coronavirusreligion.html. 
oluşmasına yol açan siyasi ve sportif etkinliklerden çok daha fazla eleştirilmiş olmasıdır. İşaret edilmesi gereken bir diğer nokta ise yine bu dönemde geleneksel dinlerin faaliyetlerine kısmen de olsa müsamaha gösterilirken azınlık konumundaki dinî grupların etkinliklerinden dolayı saldırganca bir tutumla karşı karşıya kalmasıdır. ${ }^{4}$ Geleneksel dinler gibi Yeni Dinî Hareketler de büyük oranda Covid- 19 ile mücadeleye katkı sunmaya çabalamış olmasına rağmen bu dinî yapılara karşı olanlar, Scientology gibi bazı hareketler hakkında pandemi kurallarını ihlal ederek halk sağlığını tehlikeye attıklarına dair iddialarda bulunmuşlardır. Bunun yanı sıra bazı Yeni Dinî Hareketlere ait kurumların, yardım etme bahanesiyle insanlara kendi inançlarını benimsetmeyi hedefledikleri de dile getirilmiştir. ${ }^{5}$

Söz konusu oluşumların halk sağllğına yönelik faaliyetlerini hedef alan bu iddiaların haklı ya da haksızlığı başka bir tartışmanın konusudur. Ancak söz konusu tartışmalar ekseninde, Yeni Dinî Hareketlerin salgin hastalıklara bakışı, bu tür durumlar karşısında aldıkları tavır ile sundukları çözüm önerilerinin neler olduğunu bilmek önem arz etmektedir. Buradan hareketle, bu çalışmada ilk olarak Yeni Dinî Hareketlerin salgın hastalıkları nasıl yorumladıkları ele alınmıştır. Ardından Covid-19 salgını tedbirleri kapsamında getirilen kısıtlamalara yönelik tepkileri ya da yaşanan bu kriz karşısındaki çözüm önerileri tespit edilmeye çalışılmış, son olarak da birey ve toplum sağlığını korumak amacıyla geliştirilen aşıların uygulanması karşısındaki tutum ve davranışları incelenmiştir. Bir yandan Yeni Dinî Hareketlerin sayıca çokluğu diğer taraftan salgın hastalıklara yönelik tutum ve yaklaşımların çeşitliliği, söz konusu hareketlerin tamamının konu ile ilgili düşünceleri ile pratikteki uygulamalarından bahsetmeyi oldukça zor, hatta imkânsız bir girişim haline getirmektedir. Bu nedenle örnek olarak daha ziyade Covid-19 salgını döneminde gerek dile getirdikleri söylemleri ile gerekse sergiledikleri tutum ve yaklaşımlarla öne çıkarak kendisinden söz ettirmeyi başaran hareketlere müracaat edilmiştir.

\section{1) Yeni Dinî Hareketlerin Salgın Hastalıklara Yaklaşımı}

Koronavirüs yayılmaya başladıktan sonra salgın toplumsal, ekonomik, siyasal açıdan olduğu kadar dinî perspektiften de değerlendirmeye tabi tutulmuş ve farklı inanç sistemlerinin bu tür hastalıklara nasıl baktığı gündeme gelmiştir. XX. yüzyılın ikinci

$4 \quad$ Rosita Soryte, "We Can Lift This World While Quarantined: Scientology and the 2020 Pandemic", The Journal of CESNUR 4/4, (2020): 3.

$5 \quad$ Soryte, "We Can Lift This World While Quarantined", 4. 
yarısından sonra ortaya çıkmaya başlayan ve yeryüzünün inanç haritasının önemli bir parçası haline gelen Yeni Dinî Hareketler de konu ile ilgili tartışmalardaki yerini almıştır.

Yeni Dinî Hareketlerden bazıları salgın hastalıkları dünyanın son günlerinin belirtisi olarak değerlendirmiştir. Salgın hastalıkları böyle yorumlayan hareketlerden biri Yehova Şahitleri'dir. ABD'de, 1870'li yıllarda Charles Taze Russell tarafından kurulan Yehova Şahitleri'nin inancına göre Kutsal Kitap COVID-19, AIDS ya da İspanyol gribi gibi hastalıklardan ismen söz etmemekle birlikte dünyanın son günlerinde salgın hastalıkların yaşanacağını önceden haber vermiştir. Bu yorum, Kutsal Kitap’ta geçen “Büyük depremler, birçok yerde salgın hastalıklar ve kıtlıklar olacak. Korkunç görüntüler ve gökten büyük alametler görülecek.” (Luka 21: 11) $)^{6}$ şeklindeki ifadeden çıkarılmaktadır. Yehova Şahitleri salgın hastalıkları Tanrı tarafından tüm insanlığa verilen bir ceza olarak değerlendirmemekte, bilakis Tanrı'nın gökte kurduğu krallığı aracılığıyla çok yakında salgın hastalıklar da dâhil tüm sağlık sorunlarını ortadan kaldıracağına inanmaktadırlar. ${ }^{7}$ Onlara göre Kutsal Kitap'ta yer alan şu ifadeler bu duruma işaret etmektedir:

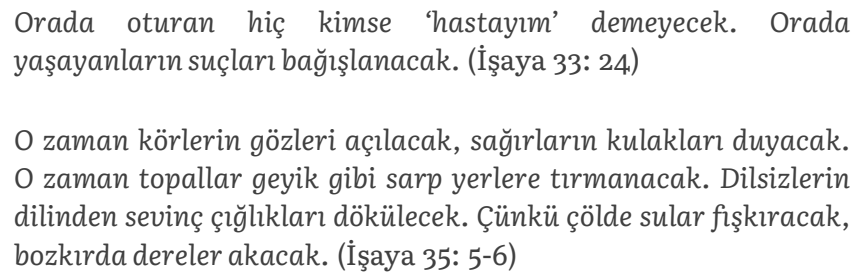

Yehova Şahitleri genel anlamda salgın hastalıkları tanrısal bir ceza olarak görmemekle birlikte Kutsal Kitap'ta Tanrı'nın insanları zaman zaman salgın hastalıklarla cezalandırdığına dair durumlardan da söz edilmektedir. Buna örnek olarak bazı insanların cüzzamla cezalandırılmasına ilişkin anlatılar verilebilir:

Miryam ve Harun, Kuşî bir kadınla evlenmesinden dolayı Musa aleyhinde konuşmaya başladilar. "Yehova sadece Musa aracılığıyla mı konuştu? Bizim aracılığımızla da konuşmadı mı?”

6 Yehova Şahitleri'nin görüşleri bağlamında başvurulan Kutsal Kitap ifadeleri, bu hareket tarafından 1970'lerde tercüme edilip tamamlanan Kutsal Kitap-Yeni Dünya Çevirisi'nden alınmıştır (Kutsal Kitap-Yeni Dünya Çevirisi, erişim: 10.09.2021, https://www.jw.org/tr/kutuphane/kutsal-kitap/bi12/kitaplar/).

7 Yehova'nın Şahitleri, “Kutsal Kitap Salgın Hastalıklar Hakkında Ne Der?”, erişim: 23.08.2021, https://www.jw.org/tr/kutsal-kitabin-ogrettikleri/sorular/kutsal-kitapsalginlar-hakkinda-ne-der/. 
diyorlardl. Ve Yehova bunlarl duyuyordu. Musa yeryüzündeki tüm insanlardan çok daha yumuşak başl biriydi. Ve Yehova ansızın Musa, Harun ve Miryam'a “Üçünüz de Toplanma Çadırına gidin" dedi. Onlar da gittiler. Yehova bulut sütununda aşağı indi ve çadırın girişinde durdu; Harun ve Miryam'ı çağırdı; ikisi de yaklaştı. Onlara şöyle dedi: "Şimdi söyleyeceklerimi dinleyin. Eğer aranızda Bana hizmet eden bir peygamber olursa, Ben Yehova, bir görüntüde Kendimi ona tanttrim. Onunla rüyada konuşurum. Fakat kulum Musa için böyle değil! Tüm halkım ona emanet edilmiştir. Onunla üstü kapalı değil açıl açık, yüz yüze konuşurum; o Yehova'nın suretini görür. Böyleyken, kulum Musa aleyhinde konuşmaktan korkmadınız mı?” Yehova onlara çok öfkelendi ve oradan gitti. Bulut çadırın üstünden çekildi ve Miryam cüzamla vuruldu, kar gibi bembeyaz oldu. Harun dönüp baktı, Miryam cüzamla vurulmuştu. Harun hemen Musa'ya "Bağışla efendim” dedi, "Bu akılsızca dauranışımızı günah sayma! Ne olur, kız kardeşim ana rahminden etinin yarısı yenmiş olarak çıkan ölü bir çocuk gibi kalmasın!” Ve Musa Yehova'ya “Ey Tanrm, lütfen! İyileştir onu ne olur!" diye yalvardı. O zaman Yehova Musa'ya şunu söyledi: "Eğer babası onun yüzüne tükürseydi yedi gün utanç içinde yaşamayacak mıydı? Yedi gün konaklama yerinin dışında, ayr bir yerde tutulsun, sonra konaklama yerine alınsın." Bunun üzerine Miryam yedi gün konaklama yerinin dişında, ayr bir yerde tutuldu. Miryam konaklama yerine geri alınana dek halk yola çımmadı. Sonra Hatserot'tan ayrıldılar ve Paran Çölüne gelip orada konakladılar. (Sayllar 12: 1-16)

Fakat Tanr adamı Elişa'nın hizmetkârn Gehazi kendi kendine şöyle dedi: "Efendim bu Arami Naaman'a yük olmamak için getirdiklerini kabul etmedi. Ama Yehova'nın hakkı için, ben arkasindan koşup ondan mutlaka bir şey alırım." Ve Gehazi Naaman'ın peşinden yola koyuldu. Naaman arkasindan birinin koştuğunu görünce onu karşılamak için arabasından indi ve "Hayrola?" diye sordu. Gehazi "Hayırdır" dedi; "Beni efendim gönderdi, 'Efraim'in dağlık bölgesinden, peygamber oğullarından iki genç geldi; onlar için lütfen bir talant gümüş ve iki takım giysi ver' diyor." Naaman "Lütfen iki talant al” dedi. Çok ısrar etti ve sonunda iki torbaya iki talant gümüş ile iki takım giysi koydu, ve bunları Gehazi'nin önü sıra taşısınlar diye iki hizmetkârına yükledi. Ofel'e geldiklerinde Gehazi hemen torbalarl ellerinden alıp eve koydu ve adamları gönderdi. Onlar da geri döndü. Gehazi gelip efendisinin önünde durdu. Elişa "Neredeydin Gehazi?" diye sordu. Fakat o "Hizmetkârın hiçbir yere gitmedi" dedi. Bunun üzerine Elişa ona şöyle dedi: "O adam seni karşllamak için yolundan dönüp arabasından indiğinde benim yüreğim orada değil miydi? Şimdi gümüşler, giysiler, zeytinlikler, bağlar, koyunlar, sığırlar, hizmetkârlar ve hizmetçiler edinme zamanı 
mı? Bu yüzden Naaman'ın cüzamı sana geçecek ve devirler boyunca senin soyundan ayrlmayacak." Gehazi derhal onun yanından çıktı, çünkü her yanını cüzam kaplamış, kar gibi beyaz olmuştu. (2.Krallar 5: 20-27)

Fakat güçlenince yüreğini öyle bir kibir kapladı ki, kendi yıkımına yol açtı. Tanrısı Yehova'ya sadakatsizlik etti ve buhur sunağında buhur yakmak için Yehova'nın mabedine girdi. Hemen ardından da kâhin Azarya ve Yehova'nın seksen cesur kâhini girdi. Kral Uzziya'nın karşısına dikilerek "Ey Uzziya, Yehova'ya buhur yakmak senin işin değil!" dediler. "Buhur yakmak, bu iş için kutsanmış Harun soyundan kâhinlerin işidir. Kutsal mekândan çık, çünkü sadakatsizlik ettin. Bu yaptığın Yehova Tanrı'ทın önünde sana onur kazandırmaz." O sırada buhur yakmak için buhurdan elinde tutan Uzziya kâhinlere çok öfkelendi. Böyle öfkeliyken, Yehova'nın evindeki buhur sunağı yanında duran kâhinlerin önünde, aniden alnında cüzam çıktı. Yüksek kâhin Azarya ve tüm kâhinler ona baktllar ve alnindan cüzamla vurulduğunu gördüler. Telaş içinde onu oradan çıkardılar; kendisi de çıkmak için acele etti, çünkü Yehova ona ağır bir darbe indirmişti. Kral Uzziya öldüğü güne kadar cüzamlı kaldı ve ayrı bir evde görevinden uzak yaşadr; çünkü Yehova'nın eviyle ilişkisi kesilmişti. Bu strada kral evinin başında olan oğlu Yotam memleket halkın da yönetiyordu. (2.Tarihler 26: 16-21)

Kutsal Kitapta geçen bu ifadeler incelendiğinde bahsi geçen olaylarda hastalığın rastgele herkese bulaşmadığına dikkat çekildiği görülmektedir. Buna göre masum insanlar hastalıktan etkilenmemiş, sadece Tanrı'ya açıkça isyan eden kişiler cezalandırılmıştır. ${ }^{8}$ Kaldı ki Yehova Şahitleri'ne göre iman eden kişiler hastalıktan muaf tutulmuş değildir. Dolayısıyla inanan insanlar da hastalıkla mücadele etmek durumunda kalabilirler. ${ }^{9} \mathrm{Bu}$ nedenle her hastalığa maruz kalan, Tanrı'nın memnun olmadığı kişi olarak nitelendirilemez. Zira Kutsal Kitap'ta Tanrı'nın sadık kullarının da çeşitli hastalıklarla mücadele ettiğine işaret edilmektedir. ${ }^{10}$

$8 \quad$ Yehova'nın Şahitleri, “Kutsal Kitap Salgın Hastalıklar Hakkında Ne Der?”.

9 Bu yorumun dayanağı 1.Timoteos 5: 23'te geçen "Midenin sağlığı ve sık sık baş gösteren rahatsızlıkların için, artık su içme, biraz da şarap iç” ifadesidir.

10

"Güneş altında olanlara dönüp baktım: Yarışı hep hızlı olan kazanmıyor; savaşı yiğitler, yiyeceği hikmetliler, serveti anlayışlılar, itibarı da bilgililer kazanmıyor; çünkü hepsi beklenmedik zamanda beklenmedik olaylarla karşılaşıyor." (Vaiz 9: 11) pasajında geçen "beklenmedik zamanlarda beklenmedik olaylarla karşılaşılması" ifadesini Yehova Şahitleri ayrıca Tanrı'nın sadık kullarının hastalıklara yakalanmasının ardındaki temel neden olarak da zikretmektedir (Yehova'nın Şahitleri, “Kutsal Kitap Salgın Hastalıklar Hakkında Ne Der?”). 
Bütün bu ifadelerden hareketle Yehova Şahitleri günümüzdeki Covid19 salgınını dünyanın son günlerinde gerçekleşecek Armagedon'un habercisi olarak görmektedir. Zira Mesih ile şeytan arasında yaşanacak olan bu manevi mücadelede hakikatin takipçileri, yani Yehova Şahitleri zarar görmeyecektir. Bu savaşın sonunda Covid-19 kurbanları da dâhil olmak üzere hastalık ve sakatlıktan muzdarip olan herkes iyileşecek, salgın veya başka bir nedenle ölenler de dirilecektir. Savaşın sona ermesi hareket üyeleri için sonsuz cennetin habercisi, Mesih'in bin ylllı yönetiminin başlangıcının işareti olacaktır. ${ }^{11}$

1830 yılında ABD'de mesihî bir hareket olarak ortaya çıkan Mormon Kilisesi, salgın hastalıkları insanların inançsızlıkları yüzünden onlara verilen ilahi bir ceza olarak telakki etmektedir. Bu konuda hareketin en temel kutsal metni olan Mormon Kitabı'nda ${ }^{12}$ şu ifadeler yer almaktadır:

\begin{abstract}
Ve O'na inanmayanlarsa ateşle ve kasirgayla ve depremlerle ve cinayetlerle ve salgin hastallklarla ve kitlılarla yok olup gidecekler. Ve onlar Rab'bin Tanrı olduğunu ve İsrail'in Kutsalı olduğunu bilecekler. (2. Nefi 6: 15)
\end{abstract}

Bu nedenle, kötülükleri yüzünden üzerlerine yıkım, kıtlık, salgın hastalık ve cinayetler gelecek; ve sağ kalanlar bütün ulusların arasına dağıtılacaktır. (2. Nefi 10: 6)

Ve söyleyeceklerim şudur: İşte, bendeki vahiy ruhuna göre şunu algilıyorum ki bu aynı halk, yani Nefililer, İsa Mesih onlara göründükten dört yüz yıl sonra inançlarını kaybedecektir. Evet ve o zaman, Nefi halkının sonu gelinceye kadar savaşlar ve salgın hastalıklar, evet, kıtlıklar ve cinayetler göreceklerdir. (Alma 4.5: 10-11)

Mormonlara göre insanların salgın hastalıklara maruz kalmasının tek sebebi inançsızlıkları da değildir. İnsanların işlemiş oldukları günahlar ve yapmış oldukları kötülükler de yine salgınla cezalandırılmanın sebebi olarak görülmüştür:

Ve öyle olacak ki bu halkımı korkunç felâketlerle, evet, kıtlıkla ve salgın hastalıklarla cezalandıracağım; ve bütün gün boyunca onları inim inim inleteceğim. (Mosiya 12:4)

11 George D. Chryssides, “Jehovah's Witnesses and Covid-19”, erişim: 24.08.2021, https://censamm.org/blog/jehovahs-witnesses-and-covid.

12 Mormon Kitabı'ndan yapılan alıntılar için bkz. Book of Mormon, erişim: 23.09.2021, https://www.churchofjesuschrist.org/study/scriptures/bofm?lang=eng. 
Ve büyük bir salgin hastalıkla vurulacaklar-ve bütün bunları işledikleri kötülükler ve iğrençlikler yüzünden yapacağım. (Mosiya 12: 7)

Fakat, sizin canınız doğru insanların duaları sayesinde bağışlanmıştır; şimdi bu yüzden, aranızdan doğruları kovarsanız, o zaman Rab elini çekmeyecek, ama kızgın öfkesiyle sizin üzerinize gelecektir; o zaman kıtlıkla, salgin hastalıklarla ve kılıçla vurulacaksınız; ve eğer tövbe etmezseniz, bunun vakti gelmiştir. (Alma 10: 23)

İşte, sen Nefi'sin ve ben de Tanr'yım. İşte sana meleklerimin huzurunda bildiriyorum ki sen bu halkın üzerinde yetki sahibi olacaksın ve bu halkın kötülüklerine göre toprağı açlıkla, salgın hastalıkla ve yıkımla vuracaksın. (Helaman 10: 6)

Ve onlar kurdukları kötü çeteler yüzünden Rab'bin sözüne hiç kulak vermediler; bu nedenle bütün ülkede savaşlar ve çekişmeler ve ayn zamanda birçok kıtlık ve salgın hastalıklar çıkmaya başladı; öyle ki yeryüzünde şimdiye kadar hiç bilinmeyen bir yıkım yaşandr; ve bütün bunlar Şiblom'un zamanında oldu. (Eter 11: 7)

\section{2) Salgınlar Karşısında Sergilenen Tutum ve Davranışlar}

Yeni Yeni Dinî Hareketlerde, salgınların yorumlanması konusunda ortaya çıkan fikir ayrılıkları bu tür hastalıklar karşısında alınan tedbirlerin desteklenmesi noktasında da kendisini göstermiştir. $\mathrm{Bu}$ çerçevede bazı hareketler hastalıktan korunmak için gereken önlemleri hiç vakit kaybetmeden uygulamaya koyarken bazıları ise resmi kararlar alınmış olmasına rağmen konuyla ilgili adım atmayı geciktirme yoluna gitmiştir.

Mesela Yehova Şahitleri, bir salgın meydana geldiğinde kişilerin gerek kendilerini gerekse başkalarını hastalıktan koruyabilmeleri için önlemlerin alınması gerektiğini savunmuştur. ${ }^{13} \mathrm{Bu}$ nedenledir ki hareket üyeleri Covid-19 salgını baş gösterdiğinde hükümetler henüz kısıtlamalar koymadan önce ev ziyaretlerini durdurmuşlardır. Sokağa çıkma yasaklarının uygulanmaya başlamasıyla birlikte İbadet Salonları'nda yaptıkları halka açık toplantıları bırakmışlardır. ${ }^{14}$ Buna karşın bazı ibadet ve toplantılar, çevrim içi araçlar kullanılarak gerçekleştirilmeye çalışılmış

\footnotetext{
13 Özdeyişler 22: 3

14 Chryssides, “Jehovah's Witnesses and Covid-19".
} 
ve bu bağlamda hareket üyeleri Zoom ve Teams gibi platformlar üzerinden planlanan online programlara katılmaya teşvik edilmiştir. ${ }^{15}$

Yehova Şahitleri ayrıca, Covid-19 salgını esnasında, uygulanmasında yarar görülen bazı önerilerde bulunmuştur. Bu öneriler, resmi internet sitelerinde şu şekilde sıralanmıştır:

1. Panik Yapmayin. Salgin hastalıklar konusunda tetikte olmak ve makul önlemler almak önemliyse de aşırı kaygıya kapılmamalıyız. Gerçeklere dayanan dengeli bir yaklaşıma sahip olmalıyız (Özdeyişler 14:15; İşaya 30:15).

2. Devletin Öneri ve Talimatlarina Uyun. Genelde yerel yetkililer halkın sağlığı için bazı önlemler alırlar ve çeşitli kısıtlamalar getirirler. Devletin talimatlarından haberdar olmak ve bunlara uymak iyi olacaktır (Romalılar 13:1).

3. Hijyene Önem Verin. Slk sık ellerinizi sabun ve suyla yıkayın ya da alkol içeren bir dezenfektan kullanın. Ayrıca evde ve İbadet Salonlarında sıkça dokunulan yüzeyleri temiz tutmaya özen gösterin. Uzmanlar böyle zamanlarda tokalaşmamayı öneriyor çünkü bu, hastalığın yayılmasına sebep olabilir. Dünya Sağlık Örgütü koronavirüs hakkında bazı ek tavsiyelerde bulundu.

4. Başkalarına Seugi Gösterin. İbadetlere katılmak ve hizmete çlkmak hepimiz için çok önemli olsa da hastaysanız, hastalığınızı başkalarına bulaştırmamak için evde kalmanız en iyisi olacaktır. Bunu yaparak kardeş sevgisi gösterirsiniz ve hem iman kardeşlerinizi hem de Şahit olmayan komşularınızı hastalıktan korumuş olursunuz (Matta 22:39).

5. Cemaatinizin Yaptığı Geçici Düzenlemelere Uyun. Salgın yaşanan bölgelerde Büronun ibadetleri, kongreleri ve diğer teokratik faaliyetleri bir süreliğine iptal etmesi gerekebilir; Güney Kore, İtalya ve Japonya'da COVID-19 virüsünün en çok yayıldığı bölgelerde olduğu gibi. İhtiyarlar yerel koşullara bağlı olarak müjdecilerin kaydedilen ibadetleri evde izleyebilmesi için bir düzenleme yapabilir. Müjdeciler telefon, mesaj, e-posta ya da mektup yoluyla şahitlikte bulunmaya devam edebilir. ${ }^{16}$

Yehova Şahitleri'ne göre Koronavirüs salgını her ne kadar bir endişe kaynağı olsa ve korunma ihtiyacı ortaya çıkarsa da korkulmaması gereken

15 Chryssides, “Jehovah's Witnesses and Covid-19”.

16 Yehova'nın Şahitleri, “Koronavirüsle İlgili Son Gelişmeler ve Hastalıktan Korunmanin Yolları”, erişim: 23.08.2021, https://www.jw.org/tr/haberler/jw/bolgelere-gore/dunyadan-haberler/jwkoronavirus-gelismeler-ve-onlemler/. 
bir durumdur. Zira yukarıda da işaret edildiği üzere Yehova Şahitleri bu sürecin kendileri için olumsuzluk doğurmayacağına inanmaktadır.

Yeni Dinî Hareketlerin salgın hastalıklar karşısındaki tutum ve yaklaşımları konusunda verilebilecek bir başka örnek 1950 yılında Lafeyette Ron Hubbard tarafindan ABD'de kurulan Scientology Hareketi'dir. Scientology, "hastalığı önlemenin onu tedavi etmekten daha öncelikli ve değerli olduğu" anlayışıyla konuya yaklaşmış ve bu bağlamda Covid-19 salgını sürecinde büyük toplantılarını iptal etmiştir. Bunun yanı sıra bültenler yayınlayarak taraftarlarına da sağduyu çağrısında bulunmuştur. ${ }^{17} \mathrm{Bu}$ çerçevede hareketin günümüzdeki lideri David Miscavige tarafından 13 Mart 2020 tarihinde yayınlanan Inspector General Network Bulletin başlıklı dokümanda şu maddelere yer verilmiştir:

İlki siz ve yakın çeureniz için gerçek bilgiler. Bu bilgileri içeren kitapçlklar, tüm personele ve halka - arkadaşlara, aileye ve meslektaşlara ücretsiz olarak dağıtılmak üzere sağlanmıştır.

İkincisi, bu virüsün her ne ise önlenmesi ya da öldürülmesi. Bu virüs ya da herhangi bir virüs, bakteri veya mikrop istilasın ortadan kaldırmak için en etkili ürünleri araştırdık ve kullanıyoruz. Havadaki yoğun ozon infüzyonlarının yanı sira peroksit ve decont püskürtülmesi buna dâhildir. (Bu uygulamalar görmediyseniz boş mekanlarda işlem yapıldığ içindir.)

Üçüncüsü, tıbbi kontroller ve izolasyon. Hasta kişilerin izole edilmesi (ayrn mahallelerde ve genel nüfusla temas halinde olmayacak şekilde) uzun süredir LRH* Sea Organization politikası olmuştur. Bu, hastalığın nasıl önleneceğine ilişkindir. Bu nedenle önleyici bir tedbir olarak tüm personel ve halk her gün, dinî törenlerden/ibadetlerden önce ateşlerini ölçtürür. Bu, tüm personelin ve halkın Organizasyonun alanlarma girmeden önce herhangi bir hastalık hissini bildirmesi şartına kadar uzanır.

Son olarak, dışarı çıktıklarında (benzin istasyonu, süpermarket vb.) ve kendilerini izole etmek istediklerinde tüm halk için eldiven ve maske mevcuttur. ${ }^{18}$

17 Soryte, "We Can Lift This World While Quarantined", 6.

LRH: Scientology Hareketi'nin kurucusu L. Ron Hubbard. Sea Organization:

Scientology'ye bağlı bir kuruluş.

18

Inspector General Network Bulletin, erişim: 03.09.2021, https://scientologymoneyproject.com/wp-

content/uploads/securepdfs/2020/03/David-Miscavige-Inspector-General-NetworkBulletin-No-88.Coronavirus.pdf. 
Benzer şekilde 1966'da Bhaktivedanta Swami Prabhupada tarafından ABD'de kurulan Hare Krishna da dünyanın farklı bölgelerinde faaliyet yürüten mabet ve toplanma merkezlerini kapatarak virüsün yayılmasını engelleme noktasında adım atmıştır. ${ }^{19}$ Ayrıca Japonya'da Covid-19'un ortaya çıkmasını takiben Yeni Dinî Hareketler, Şubat ayının ortalarından itibaren kişisel temasları askıya almıştır. Gazeteciler yaptıkları araştırmalar neticesinde, Covid-19 salgını sürecinde geleneksel dinlerin aksine Yeni Dinî Hareketlerin Japonya'da ofislerini ilk kapatan ve katılımclarıyla uzaktan iletişim kurmayı şart koşan organizasyonlar olduğu bilgisini paylaşmışlardır. ${ }^{20}$

Öte yandan tedbirlere uyma konusunda kayıtsız davranan bazı hareketlerden de bahsedilebilir. Bu bağlamda, Lee Man Hee tarafından 1984 yılında Güney Kore'de kurulan kıyametçi ve mesiyanik bir dinî yapılanma olan Shincheonji, virüsün yayılması konusunda kendilerine yöneltilen eleştirilerle dikkat çekmiştir. ${ }^{21}$ Öyle ki Covid-19 salgının ilk aylarında, virüsün yayılmasına sebep oldukları gerekçesiyle 2020 yılı Şubat ayına kadar 1.3 milyon Koreli imza toplayarak hükümetten söz konusu hareketin dağıtılması talebinde bulunmuştur. ${ }^{22}$ Hatırlanacağ üzere koronavirüsün hızlı bir şekilde yayılması üzerine her ülkede kalabalık ortamların oluşmasını engelleyici tedbirler alınmıştır. Güney Kore hükümeti de bu yönde atım atmış ve birtakım yasaklar belirlemiştir. Ancak Shincheonji'nin lideri Lee Man Hee, koronavirüsü "tarikatin büyümesini engellemeye çalışan şeytanın işi” olarak nitelendirmiş, bu anlayış doğrultusunda da toplu ayinleri devam ettirmiştir. Bu durum Kore'de vaka sayılarının artmasına neden olmuştur. Zira bu ayinlere bağlı olarak kısa süre içinde 5000 kişi enfekte olmuştur. Neticede, pandemi nedeniyle hükümet tarafından konulan bir araya gelme yasağını delen tarikat lideri gözaltına alınmış, fakat bir süre sonra serbest bırakılmışlardır. ${ }^{23}$

19 ISKCON, “The News Agency of the ISKCON", erişim: 01.09.2021, https://iskconnews.org/covid-19/?page=6.

Levi McLaughlin, “Japanese Religious Responses to COVID-19: A Preliminary Report”, The Asia Pacific-Journal 18/9 (2020): 3-4.

${ }^{21} \quad$ Muhammet Yeşilyurt, "Shincheonji İsa Kilisesi", Yeni Dini Hareketler Ansiklopedisi, ed. Süleyman Turan \& Emine Battal (İstanbul: Okur Akademi Yayınları, 2020), 479.

22 Esther Chung \& Alannah Hill, "What Is The Shincheonji Church of Jesus and Who Are Its Members? And More Importantly, What Are Its Links to The Coronavirus?", KoreaJongAng Daily, erişim: 11.10.2021,

https://koreajoongangdaily.joins.com/news/article/article. aspx? aid=3075027.

23 BBC News, "Coronavirus: South Korean Shincheonji Sect Leader Arrested", erişim: 11.10.2021, https://www.bbc.com/news/world-asia-53620633; Massimo Introvigne, “Shincheonji”, erişim: 07.09.2021, https://wrldrels.org/2019/08/29/shincheonji/. 


\section{3) Salgın Hastalıkların Tedavisi ve Aşı ile İlgili Yaklaşımlar}

Yeni Dinî Hareketlerin salgınlara bakışı çerçevesinde değinilmesi gereken bir başka husus hiç şüphesiz ki bu tür hastalıkların giderilmesinde hangi yollara başvurdukları ya da önerilen tedavi yöntemlerine nasıl tepki verdikleridir. Mesela söz konusu hareketlerden bazıları salgınların önlenmesinde herhangi bir katkısının olmayacağına işaret ederek tıbbi tedavilere sıcak bakmamıştır. Diğer bazı hareketler ise bu noktada bilime güvenilmesi gerektiğine dikkat çekerek üyelerini tıbbi tedavileri kabul etmeye teşvik etmiştir. Nitekim bu farklı bakış açısı, koronavirüse karşı vücudun bağışıklı̆̆ının geliştirilmesini sağlayan, koruyucu bir tedavi yöntemi olan aşılarla ilgili yaklaşımlarda da karşımıza çıkmaktadır.

Söz konusu tartışmalar çerçevesinde öncelikle Yehova Şahitleri'nin yaklaşımları ele alınabilir. Bilindiği üzere Yehova Şahitleri, Kutsal Kitap ilkeleri ile çeliştiği gerekçesiyle kan ve organ nakli gibi bazı tedavi şekillerini kabul etmemektedir. Bununla birlikte tıbbi tedavilere bütünüyle karşı çıkma durumu da söz konusu değildir. Zira Kutsal Kitap ilkeleriyle çelişmediği düşünülen tedavi yöntemlerinden yararlandıkları ve ilaç kullandıkları bilinmektedir. Söz konusu tedavi yöntemlerinden hangisini tercih edeceği ise kişilerin kendi kararlarına bırakılmaktadır. Bu nedenledir ki bir Yehova Şahidi herhangi bir tedavi yöntemini ve ilacı kullanmayı tercih ederken bir başkası bunu kabul etmeyebilmektedir. ${ }^{24}$

Yehova Şahitleri'nin aşı ile ilgili tutum ve yaklaşımlarda da söz konusu değişkenliği görebilmek mümkündür. Dolayısıyla Yehova Şahitleri'nde aşıya karşı topyekün bir onay ya da karşıtlık durumuna rastlanmamaktadır. Aşı olmak ya da çocuklarına aşı yaptırmak her bir hareket üyesinin kendisinin vermesi gereken bir karar olarak görülmektedir. Hareketin bir aşı karşıtlığı ve yönlendirme yapmayıp kararı üyelerine bırakmasına bağlı olarak birçok Yehova Şahidinin aşı yaptırdığ da ifade edilmektedir. ${ }^{25}$

Hare Krishna hareketinde de benzer şekilde aşı konusunda herkesin bireysel olarak karar alabileceğine vurgu yapılmaktadır. Bununla birlikte doktorların açıklamalarına ve bilimsel çalışmaların verilerine güvenilmesinin yerinde olacağı da ifade edilmektedir. Nitekim bahsi geçen veriler salgının üstesinden gelinebilmesi için dünya nüfusunun \%75'inin

24 Yehova'nın Şahitleri, “Yehova'nın Şahitleri Tıbbi Tedaviyi Kabul Eder Mi?”, erişim: 23.08.2021, https://www.jw.org/tr/yehovanin-sahitleri/sss/yehovanin-sahitleritibbi-tedavi/.

25 Yehova'nın Şahitleri, “Yehova'nın Şahitleri Aşıya Karşı mı?”, erişim: 23.08.2021, https://www.jw.org/tr/yehovanin-sahitleri/sss/yehovanin-sahitleri-asi/. 
aşılanması gerektiğini ortaya koymaktadır. Böylece Hare Krishna salgının üstesinden aşıyla gelinebileceğine dikkat çekmektedir. ${ }^{26}$ Öte yandan Hare Krishna üyeleri arasında dinî sorumlulukların yerine getirilebilmesi adına kişilerin ellerinden gelenin en iyisini yapmakla mükellef olduğu ve bu doğrultuda da tıbbi tavsiyelerin aşıdan yana olmasından hareketle aşı olmaya karar verdiklerini söyleyenlere de rastlanmaktadır. ${ }^{27}$

Aşı konusunda tereddütlü bireylerin ya da aşı karşıtlarının oransal olarak en azından üyelerin yarısının teşkil ettiği gruplar da bulunmaktadır. Mormonlar bu kategorinin örnekleri arasında zikredilebilir. Nitekim yapılan bir araştırmaya göre de Mormonların yarısı Covid-19 aşısı konusunda tereddütlü ya da aşıyı reddeden kişilerden oluşmaktadır. Öyle ki hareketin liderleri, üyeleri aşı olmaya davet etmesine karşın Mormonların yarısı aşı olmayı istememektedir. ${ }^{28}$ Mormonlar örneğinde görüldüğü üzere bazı gruplarda liderler takipçilerini aşı olmaya teşvik ederken, bazı hareketlerde ise liderler tarafından aşı karşıtlığı yapılmaktadır. 2006 yılında ABD'de ortaya çıkan Küresel Vizyon Kutsal Kitap Kilisesi'nin kurucusu ve lideri Gregory Duane Locke, Covid-19 aşısına karşı söylemleriyle dikkat çekmiştir. Locke, Koronavirüs salgını hakkında pandeminin bir aldatmaca olduğunu, ölüm raporlarının manipüle edildiğini ileri sürmüştür. $\mathrm{Bu}$ iddialarına ayrıca aşıların tehlikeli olduğunu ve virüsün kendisinden çok daha fazla ölüme yol açacağını da eklemiştir. Locke bu kadarla da yetinmemiş ve bu süreçte cemaatinin toplantılarını iptal etmeyerek maske ve sosyal mesafe kurallarını ihlal etmiştir. ${ }^{29}$

26 Bhakti Bhringa Govinda Swami, "Why I Decided That Getting Vaccinated Was the Right Choice for Me", erişim: 01.09.2021, https://iskconnews.org/why-i-decidedthat-getting-vaccinated-was-the-right-choice-for-me,7728/.

27 Hrdayananda Das Goswami, "Why I Decided that Getting Vaccinated Against COVID-19 Was the Right Choice for Me", erişim: 02.09.2021,

https://iskconnews.org/why-i-decided-that-getting-vaccinated-against-covid-19was-the-right-choice-for-me-6,7769/.

28 Religion News Service, "Half of US Mormons are COVID-19 'vaccine hesitant' or 'vaccine refusers,' study shows”, erişim: 24.08.2021,

https://religionnews.com/2021/05/06/half-of-us-mormons-are-covid-19-vaccinehesitant-or-vaccine-resistant-study-shows/; Church News, "Timeline: How the Church has Responded to the Global COVID-19 Pandemic", erişim: 24.08.2021, https://www.thechurchnews.com/history-revisited/2021-03-10/covid-19-churchresponse-timeline-missionaries-temples-191247.

29 David G. Bromley, “Global Vision Bible Church”, erişim: 17.10.2021, https://wrldrels.org/2021/10/10/global-vision-bible-church-2/; Barry Duke, "The Tide is Turning against COVID-Denying Pastor Greg Locke", Patheos, erişim: 24.08.2021, https://www.patheos.com/blogs/thefreethinker/2021/08/the-tide-isturning-against-covid-denying-pastor-greg-locke/. 
Bunların haricinde kendi alternatif tekniklerinin salgının önlenmesinde etkili olabileceği iddiasında bulunan hareketler de bulunmaktadır. 1992 yılında, Li Hongzhi tarafından Çin'de kurulan Falun Gong bu tür gruplar arasında zikredilebilir. Zira Tayvan'da yapılan bir araştırmaya göre Falun Gong'un özel nefes alma egzersizleri, meditasyonlar, diyetler, jimnastik aktiviteleri gibi uygulamaları, hareket üyelerinin kronik hastalıklarında iyileşme yaşanmasında ve Covid-19 hastalarının ciddi komplikasyonlar geliştirmesi için yüksek risk faktörü oluşturan sigaranın bırakılmasında önemli bir rol oynamıştır. Bu araştırmanın sonuçlarından yola çıkarak Falun Gong, kendi uygulamalarının Covid-19'un önlenmesi ve bu virüse bağlı ölüm riskini azaltması noktasında potansiyel bir faydaya sahip olduğunu ileri sürmüştür. ${ }^{30}$

Bazı hareketler ise salgın hastalıklarla en etkili mücadele yolu olarak duayı önermiştir. Bunlara bir örnek olarak 1941 yılında Joseph Ayo Babalola tarafından Nijerya'da kurulan Mesih Apostolik Kilisesi verilebilir. Mesih Apostolik Kilisesi, Birinci Dünya Savaşı sonrasında ortaya çıkan grip salgınına dua yoluyla çare bulmaya çalışmış, hatta insanlara sunduğu bu manevi tedavi yolu ile birçok kişinin hayatını kurtarabildiğini iddia etmiştir. Bu söylem hareketin ün kazanmasına ve taraftar bulmasında oldukça etkili olmuştur. ${ }^{31}$ Mesih Apostolik Kilisesi, koronavirüs salgınında da aynı uygulamayı devam ettirmiş, çeşitli ülkelerde virüse karşı ilahi bir koruma kalkanı oluşturmak adına geniş çaplı dua organizasyonları düzenlemiştir. ${ }^{32}$

Paramahansa Yogananda tarafindan 1920 yılında Boston'da kurulan Kendini Gerçekleştirme Derneği (Self-Realization Fellowship) de salgına karşı dua ile mücadele etme tavsiyesinde bulunan hareketler arasında yer almaktadır. Kendini Gerçekleştirme Derneği, Covid-19 salgını ortaya çıtıktan sonra etkinliklerini hemen yeni şartlara uyarlayarak ders, meditasyon ve dua içerikli çevrimiçi programlar uygulamaya başlamıştır.

30 Weisi Yan v.dğr, "Potential Benefits of Falun Gong Practice in COVID-19 Pandemic", Alternative and Integrative Medicine 10/2 (2021), erişim: 08.09.2021, https://www.hilarispublisher.com/open-access/potential-benefits-of-falun-gongpractice-in-covid19-pandemic.pdf.

31 Elif Çekici, "Mesih Apostolik Kilisesi”, Yeni Dini Hareketler Ansiklopedisi, ed. Süleyman Turan \& Emine Battal (İstanbul: Okur Akademi Yayınları, 2020), 337.

32 News Ghana, "CAC Prays for Ghana's Protection against COVID-19", erişim: 12.10.2021, $\quad$ https://newsghana.com.gh/cac-prays-for-ghanas-protection-againstcovid-19/. 
Bununla birlikte hareket, salgının geçmesi için farklı ülkelerdeki merkezlerine dua çağrısında bulunmuş ve dua çemberi oluşturmuştur. ${ }^{33}$

\section{Sonuç}

Tarih boyunca ortaya çıkan ani ve şiddetli salgınlar incelendiğinde, bunların toplumlar için daima travmatik etkiler yarattığı görülmektedir. İnsanlık için bir tehdit olarak telakki edilen salgın hastalıklara verilen en büyük tepkilerden biri kıyametin yaklaştığı korkusu ya da ilahi bir mesaj arayışı olmuştur. Nitekim bu durum, içinde bulunduğumuz yüzyılda da değişmemiş, Yeni Dinî Hareketlerin de aralarında yer aldığı çeşitli gruplar Covid-19 salgını için aynı değerlendirmelerde bulunmuştur. Bu doğrultuda Yeni Dinî Hareketler arasında koronavirüsü, işlenen günah ve kötülükler karşısında insanlığa verilen ilahi bir ceza olarak yorumlayanlar yer aldığı gibi salgını dünyanın son günlerinin yaklaştığının habercisi olarak görenler de olmuştur.

Salgınların yorumlanmasındaki bu fikir ayrılığı Yeni Dinî Hareketlerin söz konusu hastalıkları önlemek için alınan tedbirlere ve geliştirilen tedavi yöntemlerine verdikleri tepkiler konusunda da kendini göstermektedir. $\mathrm{Bu}$ çerçevede bazı dinî hareketler yetkili makamlarla işbirliği yaparak salgının önlenmesi noktasında üzerine düşen sorumlulukları yerine getirmiş, buna karşın bazıları ise faaliyetlerinin engellenmeye çalışıldığı gerekçesiyle resmi makamlarca alınan kararlara itiraz etme yoluna gitmiştir. Tam bu noktada şunu da ifade etmek gerekir ki söz konusu karşı çıkış sadece Yeni Dinî Hareketler dediğimiz yapılar tarafından sergilenen bir tutum değildir. Zira geleneksel dinlerin çatıları altında da benzer itirazlar dile getirilmiştir. Dahası geleneksel dinlere kıyasla Yeni Dinî Hareketler pek çok yerde pandemi tedbirleri kapsamında alınan kararları ilk uygulayan gruplar arasında yer almasına rağmen yine de koronavirüsün yayılmasına neden oldukları şeklindeki ithamlardan kurtulamamışlardır. Bu bağlamda halk nazarında, faaliyetleriyle aynı ihlali gerçekleştiren geleneksel dinlere tanınan esneklik bu tür oluşumlara gösterilmemiştir.

Yeni Dinî Hareketler, Covid-19 ile mücadelede en etkili araç olan aşı konusunda da ortak bir zeminde buluşmamaktadır. Söz konusu hareketlerin bir kısmı tıbbi tedavi ve aşı ile ilgili olumlu ya da olumsuz bir yönlendirme yapmayarak kararı üyelerine bırakmayı tercih etmektedir. Bazı hareketlerde ise liderler aşının, koronavirüsten daha fazla ölüme yol

33 Hatice Keleş, “Kendini Gerçekleştirme Derneği”, Yeni Dini Hareketler Ansiklopedisi, ed. Süleyman Turan \& Emine Battal (İstanbul: Okur Akademi Yayınları, 2020), 294. 
açacağı tarzı söylemleriyle aşı karşıtlığı propagandası yapmaktadır. Diğer taraftan bazı hareketlerde ise liderler aşı olunması gerektiği yönünde tavsiyelerde bulunmalarına rağmen üyelerde bir tereddüt ya da karşıtlık ortaya çıkabilmektedir. Aslında aşı konusundaki bu farklılaşma da sadece Yeni Dinî Hareketlerde görülen, sadece onlara özgü bir durum değildir. Zira Yeni Dinî Hareketlere üye olanlarından geleneksel din mensuplarına hatta seküler çevrelere varıncaya kadar toplumun çeşitli kesimlerinde benzer söylemlerle karşılaşlabilmektedir.

Anlaşılacağı üzere gerek salgın hastalıklara bakış açıları gerek alınan tedbirler karşısındaki tepkileri gerekse tedavi yöntemleri ve aşı ile ilgili tutumları kapsamında Yeni Dinî Hareketlerin tamamı hakkında genel geçer tanımlamalar ya da değerlendirmeler yapmanın imkansızlığı ortadadır. Bu nedenle salgınla mücadelenin seyrini olumsuz yönde etkileyenleri merkeze alarak bütün hareketleri günah keçisi ilan etmek doğru bir yaklaşım olmayacaktır. Öte yandan hiç şüphesiz ki halk sağlığını korumak ve bunu tehdit eden unsurları ortadan kaldırmak da önemli bir sorumluluk alanını oluşturmaktadır. Bu doğrultuda belki Covid-19'un yayılması ve önlenmesinden yana tavır alan hareketlerle işbirliği yapılarak onlardan takipçilerine hem birey hem de toplum sağlığını koruma noktasında yükümlülüklerinin bulunduğunu sıkça hatırlatmaları istenebilir. Buna bağlı olarak söz konusu hareketler salgın sona erinceye kadar ibadet, ders ya da toplantı gibi etkinliklerini dijital platformlar üzerinden sürdürmeye teşvik edilebilir ve gerekirse bunun yasal takibi de yapılabilir.

Buna karşıllk salgın tedbirleri, tedavi yöntemleri ve aşıya itiraz ederek takipçilerinden bu yönde davranmalarını isteyen hareketlerle de mücadele edilmesi gerekmektedir. Bu noktada atılması gereken öncelikli adım bahsi geçen grupların, bilhassa tıbbi tedaviler ve aşı konusunda yaydıkları yanlış bilgilerin güvenilir kaynaklarla giderilmesi ve insanların doğru bilgilerle buluşturulmasıdır. Söz konusu hareketlerin toplum sağllğını tehdit eden olumsuz propagandalarına karşı insanların zihinlerindeki soru işaretleri giderilmelidir. Böyle bir bilinçlendirme faaliyeti sonucunda muhtemelen, salgını yok sayarak karşıtlık yapan hareketlerin söylem ve uygulamalarına yönelik bir direnç gelişecek ve böylece insanların körü körüne bu tür grupların ardına kapılıp gitmesinin de bir anlamda önüne geçilmiş olacaktır. 


\section{Kaynakça}

BBC News. “Coronavirus: South Korean Shincheonji Sect Leader Arrested”. Erişim: 11.10.2021, https://www.bbc.com/news/world-asia-53620633.

Bromley, David G. "Global Vision Bible Church”. Erişim: 17.10.2021, https://wrldrels.org/2021/10/10/global-vision-bible-church-2/.

Chryssides, George D. “Jehovah's Witnesses and Covid-19”. Erişim: 24.08.2021, https://censamm.org/blog/jehovahs-witnesses-and-covid.

Chung, Esther \& Alannah Hill. "What Is The Shincheonji Church of Jesus and Who Are Its Members? And More Importantly, What Are Its Links to The Coronavirus?". KoreaJongAng Daily, erişim: 11.10.2021, https://koreajoongangdaily.joins.com/news/article/article.aspx?aid=3075027.

Church News. "Timeline: How the Church has Responded to the Global COVID-19 Pandemic". Erişim: 24.08.2021, https://www.thechurchnews.com/historyrevisited/2021-03-10/covid-19-church-response-timeline-missionaries-temples191247.

Çekici, Elif. “Mesih Apostolik Kilisesi”. Yeni Dini Hareketler Ansiklopedisi, ed. Süleyman Turan \& Emine Battal, İstanbul: Okur Akademi Yayınları, 2020, 336338.

Das Goswami, Hrdayananda. "Why I Decided that Getting Vaccinated Against COVID-19 Was the Right Choice for Me". Erişim: 02.09.2021, https://iskconnews.org/why-i-decided-that-getting-vaccinated-against-covid19-was-the-right-choice-for-me-6,7769/.

Duke, Barry. “The Tide is Turning against COVID-Denying Pastor Greg Locke”. Patheos, erişim: 24.08.2021,

https://www.patheos.com/blogs/thefreethinker/2021/08/the-tide-is-turningagainst-covid-denying-pastor-greg-locke/.

Inspector General Network Bulletin. Erişim: 03.09.2021,

https://scientologymoneyproject.com/wpcontent/uploads/securepdfs/2020/03/David-Miscavige-Inspector-General-

Network-Bulletin-No-88.Coronavirus.pdf.

Introvigne, Massimo. “Shincheonji”. Erişim: 07.09.2021, https://wrldrels.org/2019/08/29/shincheonji/.

ISKCON. "The News Agency of the ISKCON”. Erişim: 01.09.2021, https://iskconnews.org/covid-19/?page=6.

Keleş, Hatice. "Kendini Gerçekleştirme Derneği”. Yeni Dini Hareketler Ansiklopedisi, ed. Süleyman Turan \& Emine Battal, İstanbul: Okur Akademi Yayınları, 2020, 292-295.

Knapp, Alex. "The Secret History of The First Coronavirus”. Erişim: 19.10.2021, https://www.forbes.com/sites/alexknapp/2020/04/11/the-secret-history-ofthe-first-coronavirus-22ge.

Kutsal Kitap-Yeni Dünya Çevirisi. Erişim: 10.09.2021. https://www.jw.org/tr/kutuphane/kutsal-kitap/bi12/kitaplar/.

McLaughlin, Levi. "Japanese Religious Responses to COVID-19: A Preliminary Report”. The Asia Pacific-Journal 18/9 (2020): 1-23. 
News Ghana. “CAC Prays for Ghana's Protection against COVID-19”. Erişim: 12.10.2021, https://newsghana.com.gh/cac-prays-for-ghanas-protection-against-covid-19/. Quadri, Sayed A. "COVID-19 and Religious Congregations: Implications for Spread of Novel Pathogens”. International Journal of Infectious Diseases 96 (2020): 219221.

Religion News Service. "Half of US Mormons are COVID-19 'vaccine hesitant' or 'vaccine refusers,' study shows”. Erişim: 24.08.2021, https://religionnews.com/2021/05/06/half-of-us-mormons-are-covid-19vaccine-hesitant-or-vaccine-resistant-study-shows/.

Soryte, Rosita. "We Can Lift This World While Quarantined: Scientology and the 2020 Pandemic". The Journal of CESNUR 4 / 4 (2020): 3-24.

Swami, Bhakti Bhringa Govinda. "Why I Decided That Getting Vaccinated Was the Right Choice for Me". Erişim: 01.09.2021, https://iskconnews.org/why-idecided-that-getting-vaccinated-was-the-right-choice-for-me,7728/.

TÜBA. "Covid 19 Pandemi Değerlendirme Raporu”. TÜBA, 2020.

Yan, Weisi v.dğr. "Potential Benefits of Falun Gong Practice in COVID-19 Pandemic". Alternative and Integrative Medicine 10/2 (2021). Erişim: 08.09.2021, https://www.hilarispublisher.com/open-access/potential-benefits-of-falungong-practice-in-covid19-pandemic.pdf.

Yee, Vivian. "In a Pandemic, Religion Can Be a Balm and a Risk". Erişim: 10.10.2021, https://www.nytimes.com/2020/03/22/world/middleeast/coronavirusreligion.html.

Yehova'nın Şahitleri. “Kutsal Kitap Salgın Hastalıklar Hakkında Ne Der?”. Erişim: 23.08.2021, https://www.jw.org/tr/kutsal-kitabin-ogrettikleri/sorular/kutsalkitap-salginlar-hakkinda-ne-der/.

Yehova'nın Şahitleri. “Koronavirüsle İlgili Son Gelişmeler ve Hastalıktan Korunmanın Yolları”. Erişim: 23.08.2021, https://www.jw.org/tr/haberler/jw/bolgelere-gore/dunyadan-haberler/jwkoronavirus-gelismeler-ve-onlemler/.

Yehova'nın Şahitleri. "Yehova'nın Şahitleri Tıbbi Tedaviyi Kabul Eder Mi?". Erişim: 23.08.2021, https://www.jw.org/tr/yehovanin-sahitleri/sss/yehovaninsahitleri-tibbi-tedavi/.

Yehova'nın Şahitleri. "Yehova'nın Şahitleri Aşıya Karşı mı?”. Erişim: 23.08.2021, https://www.jw.org/tr/yehovanin-sahitleri/sss/yehovanin-sahitleri-asi/.

Yeşilyurt, Muhammet. "Shincheonji İsa Kilisesi”. Yeni Dini Hareketler Ansiklopedisi, ed. Süleyman Turan \& Emine Battal, İstanbul: Okur Akademi Yayınları, 2020, 4.75-479. 